\title{
The Amount of Non-Pecuniary Damage: Actual Problems of Determination (the European Court of Human Rights Practice)
}

\author{
V. Sherstiuk \\ Taras Shevchenko National University of Kyiv, Ukraine \\ Mykolas Romeris University, Institute of Private Law, Vilnius, Lithuania \\ Corresponding author. E-mail: ledak@i.ua
}

Paper received 21.05.20; Accepted for publication 10.06.20.

\section{https://doi.org/10.31174/SEND-HS2020-232VIII40-09}

\begin{abstract}
The research deals with key problems of awarding of non-pecuniary damages in the European Court of Human Rights practice. The article thoroughly examines ECHR cases and investigates whether courts have reasonably substantiated the precondition for a claim for compensation of non-pecuniary damage of a person. Big attention paid on the grounds and circumstances which influence the amount of non-pecuniary damages. Also the criteria which ECHR uses in assessment of non-pecuniary damages are disclosed.
\end{abstract}

Keywords: Non-pecuniary damage, human rights, the amount of damage, compensation, the European Convention on Human Rights (ECtHR), The European Court of Human Rights (ECHR)

Introduction. Human rights are the most important institution in any modern society which regulates the legal status of an individual and are commonly understood as fundamental and "inherent in all human beings" [1]. This institution determines the ways and measures of influence on the legal status of an individual, the limits of invasion into personal sphere and establishes legal and other guarantees of protection and realization of rights and freedoms. The relevance of this research is that in our modern world which is full of the widespread violation of human rights and freedoms, it is hardly possible to find more significant and at the same time complicated problem that human rights protection and fair compensation in case of their violation. That were the headline statements of the Human Dimension Implementation Meeting (HDIM) in Warsaw, Poland, in September 2019, leading European forum in the fields of human rights [2]. The key issues in this area are recognized legal guarantees and mechanisms for protecting an individual in case of unlawful and illegal actions in relation to him. Moreover, the most effective of legal guarantees is considered to be judicial protection. They are to review human dimension commitments and to foster their implementation.

Since 1959 the European Court of Human Rights (ECHR) is an international judicial body charged to hear applications stating the breach of human rights (civil and political) [3]. Its jurisdiction extends to all member states of the Council of Europe that have ratified the European Convention for the protection of Human Rights and Fundamental Freedoms (ECtHR) [4], including all issues related to the interpretation and application of the convention, including interstate cases and individual complaints.

In each case of violation of the Human Rights which are fixed in the ECtHR, there is a causation of damage to the individual. Non-pecuniary damage usually means the loss of non-pecuniary character as a result of moral or physical suffering or other negative phenomena caused to the person by the unlawful acts or omissions of others. Non-pecuniary damage can be determined as harm that, unlike pecuniary damage cannot be measured in money or assessed in economic categories [5, p. 113].
In spite of the active coverage of the ECHR's practice of awarding just satisfaction, there is still a lack of analytical research aimed at identifying the Court's systemic view of the proper structure and basic principles of the functioning of the non-pecuniary damage mechanism. These include assessing the legal nature of this civil liability measure, determining the subjective composition of persons authorized to use it, specific manifestations of probable non-pecuniary losses, establishing appropriate approaches to the exercise of evidence, ensuring legal certainty in matters of awarding appropriate compensation, and the like.

The question of specifying the terminological apparatus of the institute of compensation for moral harm is very important. Talking about the right to receive compensation for non-pecuniary damages there is an article 41 in ECtHR called "just satisfaction". It means a monetary payment for the damage suffered by the victim of a human rights violation. This study uses "harm", "prejudice" or "grievance" as synonyms for "damage". The text of the Convention itself avoids the terms "damage" or "harm". It only mentions the state response required after the state has violated a human right (and potentially caused damage thereby). This response is called "satisfaction" in the Convention. Neither the Convention itself nor the Court's case-law defines "damage". The ECtHR seems to use "damage" and "harm" interchangeably. For example, the Court's Practice Directions use "non-material harm, for example mental or physical suffering", as a synonym for "non-pecuniary damage". [6]. S.Altwicker-Hàmori considers it is therefore not necessary to distinguish "damage" from "harm" [7]. At the same time, the European Convention does not disclose the essence of the term "just satisfaction" used in it, which allows the ECHR to interpret this provision independently by virtue of the competence granted to it.

Being unlawful acts - offenses, all violations of subjective rights can be considered as a direct legal occasion (private legal and factual basis) for the imposition of appropriate means of compensation and property protection. However, in order for the assignment of such a prop- 
erty burden on the obligated person to be not arbitrary, but really fair, proportional to the nature of the illegal act and its consequences, the application of civil liability measures (which include non-pecuniary damage) must be due to the presence of a number of conditions characterizing the objective and subjective sides of unlawful actions or inaction. Traditionally, under these conditions they mean directly caused property or non-property damage, the actions taken by the violator of another subjective right, the presence of a causal relationship between his behavior (or the committed offense) and the negative consequences for the victim, as well as the guilt of the offender.

The common practice of the ECHR regarding issues of compensation and the amount of non-pecuniary damage has not yet been developed. Depending on the circumstances of the case, the validity of the facts of moral suffering, and on the decisions made earlier by the courts of the respective state, the ECHR may decide to indemnify the moral damage in whole or in part or that the very recognition of a violation is an appropriate satisfaction. In addition, in a number of cases, the ECHR may itself decide on the amount of compensation for non-pecuniary damage, if the claim does not specify a specific amount, or the applicant leaves this issue to the court. Fair compensation may be awarded in respect of: 1/ pecuniary damage; 2/ non-pecuniary damage; 3/ legal costs and expenses.

The court clearly distinguishes between the concepts of material and moral harm, meaning the first damnum emergens, i.e. damage actually caused, and lucrum cessans, i.e. loss or loss of profit expected in the future. At the same time, non-pecuniary damage is practically identified by the Court with such a broad concept as nonmaterial harm. So, according to the Rules, non-pecuniary damage is harm that cannot be assessed, it can be expressed in the mental or physical suffering of the applicant. However, such a determination is by no means restrictive, allowing the Court to take a different approach to the determination whether the applicant suffered nonpecuniary damage, depending on the circumstances and characteristics of each case under consideration [8].

The aim of the article is $1 /$ to analyze how this right is protected nowadays in the ECHR practice according the assessment of non-pecuniary damages; 2/to clarify under which circumstances this right can appear and the damages are used to be compensated.

Methodology and research material. The methods which were used are: 1/system analysis for reviewing and studying the ECHR practice related to the awarding of non-pecuniary damages in different cases; 2/ comparison method for analyzing criteria which ECHR uses for calculating the amount and awarding of non-pecuniary damages, 3/ legal forecasting method for analyzing how alternative mechanisms of calculating of non-pecuniary damages will influence the theory and the practice of ECHR.

Discussion. Non-pecuniary damages, by its very nature, do not lend itself to exact mathematical calculation; therefore, the ECHR is guided by justice in determining its size. The amount and grounds for payment of this type of compensation in each particular case depend on the circumstances of the case and the case-law of the Court in cases brought against the respective respondent State.
According to the Court's case-law, non-material harm includes: physical pain and suffering; damage to health; psychological harm; emotional stress; frustration and humiliation; feelings of anxiety (injustice); feelings of uncertainty, as well as emotional experiences (distress); anxiety (inconvenience). Pain and suffering is defined as the physical and mental distress suffered after an injury. This can include broken bones and internal damage, but also any pain, aches, permanent or temporary limitations on a person's activity, shortening of life, depression, embarrassment, and other types of pain and suffering. The amount for damages is highly subjective, however, and takes experts to calculate. It is important to emphasize that pain and suffering can include physical pain and mental suffering [9].

Suffering is a person's feelings, emotions in the form of negative experiences arising under the influence of events that traumatize his psyche, deeply affecting his personality structures, mood, well-being and health. Under the moral suffering and feelings of a person should understand the feelings of humiliation, irritation, depression, shame, anger, inferiority, despair, and many others. Anxiety, anxiety state - an unpleasant, negative, difficultly experienced emotion, the components of which are feelings of tension, fear, anxiety. Anxiety arises in connection with situations that potentially carry a danger, a threat, a negative prospective for a person in the future.

However, these are not identical categories. Experience is "suffering is only negative." It can be concluded that this can be reflected in the form of experience (moral suffering) or negative feelings (bodily suffering). In addition, the ECHR classifies damage of reputation (loss of reputation) as well as harm to a good name, harm caused to relationships (loss of relationship), as well as disruption to the normal course of private life (disruption to lives)[10]. In particular, in the case of Poznakhirina v. Russia [11], the Court notes that since the applicant in the case had a well-paid job. On this basis, the Court decided that the non-payment to the applicant of the money awarded by a judicial decision did not affect her income and that it would be sufficient to justify the finding of a violation to compensate.

In determining the amount of compensation for nonpecuniary damage to individuals, generally the Court takes into account the following factors: the severity and seriousness of the violation found; the duration of the violation; the presence of serious or irreversible consequences for the applicant's health; the duration and extent of the moral and physical suffering; individual characteristics of the applicant (for example, his age and state of health), as well as the requirements of justice.

There is reason to believe that from the point of view of the ECHR of Human Rights, the prerequisite for compensating the applicant for non-pecuniary damage is not the latter as such, but rather the infliction of substantial harm to the victim, which, due to its weight or originality, requires special satisfaction for the victim account of the respondent State. We find obvious evidence of this in the decisions of the ECHR, which explicitly states that the fact of a violation of the Convention for the Protection of Human Rights and Fundamental Freedoms is sometimes sufficient satisfaction for the non-pecuniary damage caused to the applicant. In all likelihood, the practice of 
the Court in this aspect reflects the influence of German and Swiss law, in which the need to award compensation for non-pecuniary damage is explained mainly by the severity of the infringement of the rights of the individual.

In other words, the scale of the negative consequences of the offense should reach such an extent that the refusal to award compensation would have seemed clearly unfair, given the essence of the losses suffered, and obviously unreasonable from the point of view of the need to prevent the commission of similar offenses in the future and to encourage all participants in public relations to exercise due diligence. It is believed that following this approach in national law enforcement practice would avoid the danger of falling into the trap of the preservation by many scholars of the presumption of moral harm, which is allegedly present in every case of violation of one's rights. Whereas if such a presumption can be applied, it is solely for the purpose of enhanced protection of persons who are in a violated legal relationship in a deliberately vulnerable position in relation to the offender or in situations where the expediency of its use is objectively dictated by the very essence of the offense.

An example of this is the decision of the ECHR of October 15, 2009 in the case of Ivanov v. Ukraine, in which the Court, through reference to the Burdov v. Russia case, confirmed the existence of a substantiated and at the same time refuted presumption, in accordance with which overly lengthy judicial proceedings provide grounds for compensation for non-pecuniary damage. Moreover, as the Court emphasized, such a presumption is especially indisputable in the event of an excessive delay in the execution of the decision made against the state, since failure to comply with his obligation to return the debt after the applicant, having passed the trial, was successful, would inevitably cause him to feel despair [12].

What should the judge be guided in determining the amount of non-pecuniary damage in each particular case, analyze the existing practice in his region or apply the criteria of the ECHR in resolving this issue, and whether the size should depend on the personality of the victim, the degree of his emotionality, vulnerability, level of selfesteem, physical development, gender, etc. Moral harm arises as a result of physical or moral suffering. Physical suffering, a feeling of physical pain is a physiological category. Different people have different pain thresholds, different abilities to endure physical pain. And it would be wrong to believe that a blow of the same strength of a young man who plays sports and a schoolgirl's girl will cause them the same physical pain, and, consequently, the same moral harm, which can be compensated by an equal amount of money.

As for moral suffering, they can be defined as a set of negative emotions - feelings of fear, humiliation, resentment, oppression, anxiety, etc. Naturally, the degree and depth of such mental reactions directly depends on the individual characteristics of the psyche, the level of development of intelligence, self-esteem of the victim, and the position of the object, the infringement of which causes moral harm, in the value system of the victim [10].

It should be noted that in determining the amount of compensation, the ECHR does not consider itself bound by national practice, although it may be based on it. This statement is contained in a judgment of 25 February 1997 in the case of "Z. against Finland" [13]. The applicant claimed only non-pecuniary damage as a result of the disclosure of medical information about her, which was widely circulated by the press. The court found established that the applicant suffered non-pecuniary damage as a result of the disclosure of her full name and medical information about her in a decision of the Court of Appeal. He decided that adequate just satisfaction would not be ensured only by recognition of the fact of the violation itself and therefore compensation should be awarded.

Contrary to the widespread opinion about the manythousand compensation for non-pecuniary damage, the ECHR does not fully satisfy the claim for moral compensation, but determines its significantly smaller size. The court takes such decisions not only in relation to Ukraine, but also to other countries. Thus, in the judgment of June 29, 2004 in the case of Voytenko v. Ukraine, where the applicant claimed EUR 24,963.28 in respect of nonpecuniary and pecuniary damage, the court did not see a causal link between the violation found and the amount of pecuniary damage claimed, therefore dismissed the complaint [14]. As regards non-pecuniary damage, the court stated that, as a result of the violations found, the applicant had suffered non-pecuniary damage, which could not be corrected by merely ascertaining the fact of the violation by the court. However, the amount claimed is excessive. Objectively assessing the situation, as required by Article 41 of the ECtHR, the court awarded the applicant EUR 2,000 for non-pecuniary damage.

In addition, when applying to the ECHR, the applicant must clearly state what kind of compensation he wants to receive. Thus, in the judgment of September 27, 1995 in the case of McCann and Others v. The United Kingdom concerning moral and pecuniary damage, the court was unable to establish from the applicants' submissions whether the claim for financial compensation falls within the definition of pecuniary or non-pecuniary damage or under both at once [15].

The existing practice of the ECHR shows that compensation for moral damage can only be expected at the same moral level, and not at all material. In a judgment of 25 October 1993 in the case of Holm v. Sweden, the applicant claimed SEK 400,000 for non-pecuniary damage [16]. He claimed that, due to the publication of the book, he was under psychological pressure for several more years after the end of the proceedings in the national courts, and also that he had little chance of a successful court decision, given the composition of the jury. The decision noted that it was not the court's task to make assumptions; the district court would decide the dispute in favor of the applicant, considering the case in a different composition. In any event, the Court finds that the finding of a violation of Article $6 \S 1$ of the Convention in itself constitutes sufficient just satisfaction.

Nevertheless, the ECHR may make decisions on nonpecuniary damage, even if the requirements regarding it are not specified and supported by documents. So it was in the court decision of July 27, 2004 in the case of Romashov v. Ukraine [17]. In considering the application, the court drew attention to the fact that, in accordance with Rule 60 of the Rules of Court, any claim for fair satisfaction must contain a list of claims and may be submitted in writing along with relevant supporting docu- 
ments or evidence, "without which [the Court] may reject the claim fully or partially". The applicant did not provide a single document in support of his claims and did not specify them. The court took into account the fact that, as a result of the violations found, the applicant suffered non-pecuniary damage, which cannot be compensated by merely ascertaining the fact of the violation by the court. Objectively assessing the situation, as required by Article 41 of the Convention, the court awarded the applicant EUR 3,000 in compensation for non-pecuniary damage.

In addition, the court in its decision may establish a specific amount of non-pecuniary damage, despite the fact that it was not established by the applicant himself. This decision was made on January 24, 1994 in the case of Raimondo v. Italy, where the court did not recognize the claims for pecuniary damage due to the vagueness of their wording, but considering that the applicant suffered certain non-pecuniary damage, awarded him compensation in the amount of 10,000,000 Italian lire [18].

It seems erroneous that the compensation for nonpecuniary damage for mental suffering caused by a scar on a hand from a dog bite should be the same for a girl planning to start working as a model and for whom the question of how she looks comes first, and for an elderly person who is not very concerned about appearance. Indeed, if in the victim's value system his own appearance is in one of the first places, then causing damage to his appearance will cause deep feelings in him. In the case when the victim does not attach importance to the beauty of his body and does not experience negative emotions from the fact that his appearance has suffered, we can only talk about compensation for moral harm, expressed in physical pain from a dog's bite [10].

In relation to the determination of the amount of compensation for non-pecuniary damage, it is necessary in all cases to take into account the material situation of the person to whom such harm was caused. Moreover, the higher the income of the victim, the greater the amount to be recovered, since moral satisfaction of a person with a high level of income requires appropriate compensation, otherwise the principle of equality of citizens and the requirement of fair compensation will be violated. The need to take into account the financial situation of the victim in this case is dictated by the specifics of the compensated harm. In case of causing material damage, a person is deprived of a material good having a monetary value, difficulties in determining the amount of compensation may arise only in connection with the establishment of the monetary value of this good. Moral harm, as an intangible category, cannot be evaluated in monetary terms as a category exclusively material. Compensation for non-pecuniary damage is the opportunity for the victim to experience positive emotions at the expense of the amount collected, commensurate with the physical or mental suffering he has experienced. Suppose that two women suffered moral suffering of the same severity, they experienced the same amount of negative emotions. At the same time, one victim is the head of a large commercial company with a very high income level, and the other is a cleaning lady, her income is extremely low. Naturally, in order to experience positive emotions com- mensurate with the moral harm inflicted, a wealthy person needs a much larger amount of money than a low-income person. A cleaning lady can experience exactly the same positive emotions from buying a new pair of boots for the exacted money on the market, just like a manager from purchasing a brand of Louboutin shoes. Accordingly, the two persons are equally compensated for the nonpecuniary damage, although the amounts collected are not the same.

Despite the possibility of various verbal designations of the totality of the non-property consequences of the offense in connection with which compensation is awarded, other than compensation for material damage (for example, moral or non-property damage, non-material damage or non-material losses), in each case of its award we are talking about the application of the same compensation mechanism, the effect of which is entirely due to a judicial interpretation morally The legal imperatives of justice, reasonableness and good faith. Therefore, the term "Compensation for non-pecuniary damage" is an absolutely adequate generalizing designation for compensation for these losses

Given the impossibility of a reliable establishment of all manifestations and characteristics of moral harm inflicted on the victim, the construction of a speculative model of the occurrence of reasonably expected consequences of the offense reasonably expected, common in similar situations, should be considered the best way to determine its presence and its inherent individual parameters. Therefore, referring to the widespread theories of causation, it should be recognized that the theory of adequate causation is most suitable for explaining the features of the functioning of the mechanism for compensation for moral harm [19, p. 45].

It seems fair and reasonable to exclude guilt from the composition of the conditions of liability of public law entities for moral damage caused to the weak ("subject") side in public legal relations. However, this does not exclude the need to assess and compare the subjective side of the parties to the dispute in order to determine the fair amount of compensation awarded to the victim, and sometimes to determine the legitimacy of the actions of the authorities (if this legitimacy was determined by the degree of care and discretion shown by the subject of the public administration).

Conclusions. In the final analysis, it has been demonstrated that there is no stability in awarding of nonpecuniary damages by ECHR. The amount of damage awarded is usually unpredictable and there are no fixed criteria of calculating the right amount of it in each case. There were no mechanisms of fair compensation proposed and implemented to the ECHR. The criteria for determining the amount of non-pecuniary damage are not clearly defined and lead to the unfair assessment of nonpecuniary damage in the ECHR decisions. Thus, considering the number of applications to the ECHR, this analysis would surely serve as a point of departure for finding clearer mechanisms for determining the amount of nonpecuniary damage caused to individual by human rights violations. 


\section{REFERENCES}

1. Burns H. Weston, 20 March 2014, Encyclopedia Britannica, human rights, https://www.britannica.com/topic/human-rights (retrieved 23 February 2020);

2. www.osce.org/odihr/hdim_2019highlights, (retrieved 24 February 2020);

3. Human Rights Building In Figures https://www.echr.coe.int/Documents/Court_in_brief_ENG.pd f;

4. https://www.echr.coe.int/Documents/Convention_ENG.pdf (Retrieved 1 March 2020),

5. Koziol H. Basic questions of Tort law from a Germanic perspective. Wien: Jan Sramek Verlag, 2012;

6. Article 41 of the ECHR. Available at https://www.coe.int/en/web/execution/article-41;

7. Altwicker-Hamori, S. and Altwicker, T.and Peters, A., Measuring Violations of Human Rights: An Empirical Analysis of Awards in Respect of Non-Pecuniary Damage Under the ECtHR (July 16, 2015). HJIL, 76 (2016), 1-51. Available at https://ssrn.com/abstract=2631404

8. Baglaridu M.F. Compensation of moral damage in practice the echr of human rights. Moscow Journal of International Law. 2017;106 (2):154-160. (In Russ.) https://doi.org/10.24833/0869-0049-2017-106-2-154-160.

9. Human rights: Sat. international. dock. - Warsaw: Helsinki. Human Rights Foundation, 2002. 122 p.

10. Atrashkevich V. N. Moral harm - what is it? Young scientist. No. 7. 2016. 187 p.

11. Judgment of the Grand Chamber of the ECHR of February 24, 2005 on the merits of the application N 25964/02 "Poznakhirina v. Russia." Accessed 21 February 2020. https://hudoc.echr.coe.int/rus\#\{"fulltext":["Poznakhirina\%20 v.\%20Russia"],"documentcollectionid2": ["GRANDCHAMBER","CHAMBER"],"itemid":["001-68404"]\}.

12. The decision of the ECHR of Human Rights 10/15/2009. "Yuriy Mikhailovich Ivanov against Ukraine". https://hudoc.echr.coe.int/rus\#\{ "fulltext":["Ivanov\%20against \%20Ukraine"],"documentcollectionid2":["GRANDCHAMB ER","CHAMBER"],"itemid":["001-95032"]\}

13. "Case of Z v. Finland". Accessed 23 February 2020. https://hudoc.echr.coe.int/rus\#\{"fulltext":["Case\%20of\%20Z \%20v.\%20Finland"],"documentcollectionid2":["GRANDCH AMBER","CHAMBER"],"itemid":["001-145423"]\}

14. "Case of Voytenko v. Ukraine". Accessed 20 February 2020. https://hudoc.echr.coe.int/rus\#\{"fulltext":["Case\%20of\%20V oteko\%20v.\%20Ukraine"],"documentcollectionid2":["GRAN DCHAMBER","CHAMBER"],"itemid":["001-172262"]\}

15. "Case of Mccann and others v. The United Kingdom". Accessed $24 \quad$ February 2020. https://hudoc.echr.coe.int/rus\#\{"fulltext":["Case\%20of\%20M ccann\%20and\%20others\%20v.\%20The\%20United\%20Kingd om"],"documentcollectionid2":["GRANDCHAMBER","CH AMBER"]\}

16. "Case of Holm v. Sweden “. Accessed 24 February 2020. https://hudoc.echr.coe.int/rus\#\{"fulltext":["Case\%20of $\% 20 \mathrm{H}$ olm\%20v.\%20Sweden"],"documentcollectionid2":["GRAND CHAMBER","CHAMBER"],"itemid":["001-57851"]\}

17. "Case of Romashov v. Ukraine". Accessed 15 February 2020.

https://hudoc.echr.coe.int/rus\#\{"fulltext":["Case\%20of\%20R omash-

ov\%20v.\%20Ukraine"],"documentcollectionid2":["GRANDC HAMBER","CHAMBER"],"itemid":["001-125572"]\}

18. "Case of Raimondo v. Italy". Accessed 28 February 2020. https://hudoc.echr.coe.int/rus\#\{"fulltext":["Raimondo\%20v. \%20Italy"],"documentcollectionid2":["GRANDCHAMBER", "CHAMBER"],"itemid":["001-57870"]\}

19. Human rights: international legal instruments and practice of their application: in 4 vols / comp. E.V. Kuznetsova. Minsk: Amalfi, 2009. Vol. 1-4. P.45 